Open Access

\title{
A cross-sectional study to explore postgraduate students' understanding of and beliefs about sexual and reproductive health in a public university, Malaysia
}

\author{
Shahla Soleymani ${ }^{1}$, Hejar Abdul Rahman ${ }^{1 *}$, Rampal Lekhraj ${ }^{1}$, Nor Afiah Mohd Zulkefli ${ }^{1}$
} and Nasrin Matinnia ${ }^{2}$

\begin{abstract}
Background: The main sexual and reproductive health issues among young people are premarital sexual intercourse, unwanted pregnancies, unsafe abortions and sexually transmitted diseases including Human Immunodeficiency Virus. The aim of this study was to determine the knowledge related to sexual and reproductive health among Malaysian postgraduate students in a public university in Malaysia.

Methods: A cross-sectional study was carried out among postgraduate students by systematic random sampling technique. A pre-tested self administered questionnaire was used to collect the data.

Results: Out of 434 respondents, the majority of students were female (78.6 \%) and single (78.3 \%). The overall mean age of respondents was 27.0 ranging from 20 to 46 years of age. The main sources of information for sexual and reproductive health awareness were the internet (78.6\%) and newspaper (61.8\%). The majority (97.9\%) of the students knew that AIDS is a sexually transmitted disease. Most of them believed that the spread of sexually transmitted diseases was through shaking hands (92.1\%). Use of condoms was perceived to be the best way to avoid sexually transmitted diseases (88.4\%). Sexual and reproductive health knowledge was significantly associated with the students' age, marital status and faculty. The socio-demographic factors and current educational status accounted for a significant $9 \%$ of the variability in sexual and reproductive health knowledge, $f(7,426)=11, p<0.001$.

Conclusions: The postgraduate students' level of knowledge on sexual and reproductive health was not satisfactory. Sexual and reproductive health knowledge was associated with the students' marital status and faculty. Intervention programs related to sexual and reproductive health are recommended.
\end{abstract}

\section{Background}

Sexual and reproductive health (SRH) is an essential part of public health and can considerably influence the general well being and quality of life [1]. Reproductive health includes all issues related to the reproductive system and its function while sexual health indicates the ability of having a safe and satisfying sex life [2].

Annually about 500 million new cases of sexually transmitted diseases (STD) are reported all around the

\footnotetext{
* Correspondence: hejar@upm.edu.my

1 Department of Community Health, Faculty of Medicine and Health Sciences, Universiti Putra Malaysia, 43400 UPM, Serdang, Malaysia

Full list of author information is available at the end of the article
}

world among people aged 15-49 years old excluding human immunodeficiency virus (HIV) and other sexually transmitted infections [3, 4]. It is estimated, that there are almost 60 million people who are infected with HIV worldwide, of whom about 33.4 million living with HIV. Most of them are unaware that they are HIV carriers and may spread the virus to others [5].

Furthermore, unwanted pregnancy is one of the most common health problems with negative effects on individuals, families and society. It is estimated that approximately $60 \%$ of all pregnancies are unplanned [6]. The most important reason of unintended pregnancy is that no contraception methods are used [7]. According to 
World Health Organization (WHO) in 2011, about 20 million unsafe abortions happened worldwide, almost all in developing countries [8].

Young people with low level of knowledge on sexual and reproductive health are more at risk of unintended pregnancies, unsafe abortions and sexually transmitted infections including HIV [3]. The most efficient way to avoid sexually transmitted infections is having sexual intercourse within a long-term and trusted monogamous partner and using condoms consistently and correctly [4].

In Malaysia the youth SRH is influenced by sexual relationship before marriage, sexually transmitted diseases (STD) including HIV/AIDS, unintended pregnancies and unsafe abortions $[9,10]$. The Ministry of Health in Malaysia, in 2008, revealed that about $25 \%$ of HIV infections are among people aged between 20 and 29 years [11]. An investigation has shown that the average age of the first sexual intercourse is 15 years and the percentage of premarital sexual activity has increased over the years in Malaysia [10]. Youths who initiated sexual intercourse early are less likely to use contraception and are at risk of unwanted pregnancy [12]. Data regarding the prevalence of abortion are not readily available due to their legal and moral ambiguities [13]. Recently there has been a growing number of reports in media on baby dumping in Malaysia, which has attracted a lot of attention and has posed a serious challenge to the country $[14,15]$.

Sexual and reproductive health (SRH) research in Malaysia has focused on different issues and fields of SRH among adolescences and adults. Research findings indicate a range of low mean scores of knowledge among school students $[16,17]$ and university students [18-20] to high mean scores of knowledge in female staff [21].

There are not many studies on sexual and reproductive health issues among Malaysian postgraduate students. Data on sexual and reproductive health knowledge among university students are important for planning effective educational programs in universities. The objective of this study was to determine the level of knowledge related to sexual and reproductive health among Malaysian postgraduate students in a public university, Malaysia.

\section{Methods}

A cross-sectional study was conducted in a Malaysian university with 434 registered postgraduate students between September $5^{\text {th }}, 2012$ and September $15^{\text {th }}, 2012$. A systematic random sampling technique was used to select the sample. Data were collected at the School of Graduate Studies (SGS) from the list of postgraduate students during the registration timetable. Before the distribution of questionnaires, the purpose of the study was explained to them. The questionnaires took about $20 \mathrm{~min}$ to be completed and were collected immediately upon completion.
The data were collected using a self-administered pretested questionnaire in English which had been used in a study in Albania [22]. It consisted of questions related to socio-demographic factors and knowledge related to sexual and reproductive health, including STD knowledge, contraceptive knowledge and knowledge sources. Knowledge was determined using 47 questions on sexual and reproductive health with "Yes" or "No" or "Don't Know" response.

The questionnaire was pre-tested on 40 students from a university other than the actual study participants'. After pre-testing of the questionnaire, the content validity was evaluated to examine each item for congruence. The standardized Cronbach's alpha reliability coefficient was above 0.70. There were no modifications after pre-testing. This study was approved by the Ethical Committee of Universiti Putra Malaysia. A written consent was obtained from all the students before conducting the survey. All questionnaires were anonymous.

Respondents were given one point for answering correctly and zero for answering wrongly or not knowing the answer. Total knowledge scores can range between 0 and 47. Knowledge scores from 0 to 23 were considered as low knowledge while knowledge scores more than 23 was considered as having high knowledge regarding sexual health. The data were analyzed using Statistical Package for Social Sciences (SPSS) version 20.0. Comparisons among groups were made using appropriate inferential tests such as $t$-test and ANOVA. Multiple linear regression was used to determine the predictors of sexual and reproductive health knowledge. To estimate the proportion of variance in sexual and reproductive health knowledge that can be accounted for by socio-demographic factors and current educational status, multiple linear regression analysis was performed. The level of significance was set at 0.05 .

\section{Sample size estimation}

The number of postgraduate students needed for this study is calculated based on the previous study among university students in Malaysia [23]. The estimation sample size was estimated by the following formula [24].

$$
n=\frac{\mathrm{Z}_{1-\alpha} \sqrt{2 \mathrm{P}(1-\mathrm{P})}+\mathrm{Z}_{1-\beta} \sqrt{\mathrm{P}_{1}\left(1-\mathrm{P}_{1}\right)+\mathrm{P}_{2}\left(1-\mathrm{P}_{2}\right)^{2}}}{\left(\mathrm{P}_{1}-\mathrm{P}_{2}\right)^{2}}
$$

$\mathrm{Z}_{1-\alpha}=1.96, \mathrm{Z}_{1-\beta}=1.282$

$\mathrm{P}_{1}=0.41=$ Proportion of undergraduate students with poor attitude on sexual health

$\mathrm{P}_{2}=0.58=$ Proportion of undergraduate students with good attitude on sexual health

Total sample size with $20 \%$ allowance for possible drop outs $\mathrm{N}=434$ 


\section{Results}

\section{Socio-demographic characteristics of respondents}

Out of the 434 respondents, the majority (78.6 \%) were female and single $(78.3 \%)$. On average their age was 27 $( \pm$ SD 4.305) ranging from 20 to 46 years. The mean age of the males and females were $26.82( \pm$ SD 4.125$)$ year and 27.41 ( \pm SD 4.91$)$ years, respectively. Majority of the respondents $(70.2 \%)$ were Malayfollowed by $18.2 \%$ Chinese and $8 \%$ Indian. More than half of the students were Muslims (73\%) (Table 1).

\section{Knowledge on sexual and reproductive health}

The overall mean \pm SD of sexual and reproductive knowledge score was $29.69( \pm 8.26)$. In this study, the majority

Table 1 Socio-demographic characteristics of respondents $(n=434)$

\begin{tabular}{|c|c|c|c|}
\hline Variable & & Frequency & Percent \\
\hline \multirow[t]{2}{*}{ Gender } & Male & 93 & 21.4 \\
\hline & Female & 341 & 78.6 \\
\hline \multirow[t]{2}{*}{ Age (year) } & $<26$ years & 265 & 61.1 \\
\hline & $\geq 26$ years & 169 & 38.9 \\
\hline \multirow[t]{4}{*}{ Ethnicity } & Malay & 305 & 70.3 \\
\hline & Chinese & 79 & 18.2 \\
\hline & Indian & 35 & 8.1 \\
\hline & Other & 15 & 3.5 \\
\hline \multirow[t]{5}{*}{ Religion } & Islam & 317 & 73.0 \\
\hline & Christian & 22 & 5.1 \\
\hline & Buddhist & 58 & 13.4 \\
\hline & Hindu & 33 & 7.6 \\
\hline & Other & 4 & 0.9 \\
\hline \multirow[t]{2}{*}{ Marital status } & Married & 94 & 21.7 \\
\hline & Single & 340 & 78.3 \\
\hline \multirow[t]{2}{*}{ Level of education } & Master & 369 & 85 \\
\hline & $\mathrm{PhD}$ & 65 & 15 \\
\hline \multirow[t]{3}{*}{ Faculty } & Non- science & 108 & 24.9 \\
\hline & Science & 263 & 60.6 \\
\hline & Health science & 63 & 14.5 \\
\hline \multirow[t]{2}{*}{ Year of study } & First year & 349 & 80.4 \\
\hline & Others & 85 & 19.6 \\
\hline \multirow[t]{4}{*}{ Father's education } & Primary education & 57 & 13.13 \\
\hline & Secondary education & 239 & 55.07 \\
\hline & University degree & 113 & 26.04 \\
\hline & Others & 25 & 5.76 \\
\hline \multirow[t]{4}{*}{ Mother's education } & Primary education & 81 & 18.66 \\
\hline & Secondary education & 266 & 61.29 \\
\hline & University degree & 64 & 14.75 \\
\hline & Others & 23 & 5.30 \\
\hline
\end{tabular}

( $97.9 \%$ ) of the students knew AIDS is a sexually transmitted disease however, only a few (24.4\%) were aware of chlamydia. About $83.9 \%$ perceived a person can acquire STD by receiving blood transfusion from an infected person and $73 \%$ believed that a pregnant woman with STD/HIV can passthe disease to her unborn baby (Table 2).

The present study also showed that respondents had incorrect knowledge about STD prevention methods. More than half of the participants believed that the spread of sexually transmitted diseases was through public toilet (77.4 \%), through kissing (64.5\%) and through shaking hands (92.1\%). However, most respondents believed that "use of condoms" (88.5\%), as well as "having one uninfected faithful sex partner" (85.7\%) can reduce the risk of sexually transmitted diseases. A few respondents (20.7\%) recognized abstinence from sex as a method of preventing sexually transmitted diseases.

In terms of the contraceptive methods knowledge, most of the respondents were aware of condoms $(87.6 \%)$, oral contraceptives (72.4\%), intrauterine device (IUD) (57.4\%), followed by morning after pill (45.4\%) and injectable contraception (49.1\%). In addition, a high percentage of the respondents $(79.3 \%)$ knew where to refer to when in need of medical treatment for sexual health issues.

This study shows that the most frequent sources of SRH information were internet (78.6 \%) and newspaper (61.8 \%). In contrast, parents (13.8 \%) and friends (32.3\%) were the least frequent sources.

\section{Relationship between socio-demographic factors, current educational status and sexual and reproductive health knowledge}

There were significant associations between age, marital status and faculty with sexual and reproductive health knowledge of the students (Table 3 ).

\section{Sexual and reproductive health knowledge and associated factors}

A standard multiple regression was conducted to estimate the prediction of knowledge by socio-demographic factors and current educational status. Multiple linear regression analysis showed that sexual and reproductive health knowledge were associated with marital status and faculty of the students. However age, gender, ethnicity, religion and year of study were not associated with sexual and reproductive health knowledge. The assumptions of normality, linearity and homoscedasticity of residuals were met. In combination, socio-demographic factors and current educational status accounted for a significant $9 \%$ of the variability in sexual and reproductive health knowledge, $R^{2}=0.09$, adjusted $R^{2}=0.074$, $f(7,426)=11, p<0.001$ (Table 4). 
Table 2 Sexually transmitted diseases knowledge $(n=434)$

\begin{tabular}{|c|c|c|c|}
\hline Item & Yes & No & Don't know \\
\hline 1. Syphilis is a sexually transmitted disease. & $353(81.3)$ & $7(1.6)$ & $74(17.1)$ \\
\hline 2. Chlamydia is a sexually transmitted disease. & $106(24.4)$ & $46(10.6)$ & $282(65.0)$ \\
\hline 3. HIV/AIDS is a sexually transmitted disease. & $425(97.9)$ & $3(2.7)$ & $6(1.4)$ \\
\hline 4. Pneumonia is a sexually transmitted disease. & $237(54.6)$ & $27(6.2)$ & $170(39.2)$ \\
\hline 5. Hepatitis is a sexually transmitted disease. & $188(43.3)$ & $106(24.4)$ & $140(32.3)$ \\
\hline 6. Gonorrhea is a sexually transmitted disease. & $161(37.1)$ & $57(13.1)$ & $216(49.8)$ \\
\hline 7. Trichomonasis is a sexually transmitted disease. & $51(11.8)$ & $52(12.0)$ & $331(76.3)$ \\
\hline $\begin{array}{l}\text { 8. Sexually transmitted infections can be transmitted by receiving blood transfusion from } \\
\text { an infected person. }\end{array}$ & $364(83.9)$ & $44(10.1)$ & $26(6.0)$ \\
\hline 9. Sexually transmitted infections can be transmitted by using public toilets. & $336(77.4)$ & $56(12.9)$ & $42(9.7)$ \\
\hline 10. Sexually transmitted infections can be transmitted through kissing. & $280(64.5)$ & $106(24.4)$ & $48(11.1)$ \\
\hline 11. Sexually transmitted infections can be transmitted by unprotected sexual activity. & $412(94.9)$ & $9(2.1)$ & $13(3.0)$ \\
\hline 12. Sexually transmitted infections can be transmitted by unprotected intercourse. & $349(80.4)$ & $26(6.0)$ & 59 (13.6) \\
\hline 13. Sexually transmitted infections can be transmitted through shaking hands. & $400(92.2)$ & $7(1.6)$ & $27(6.2)$ \\
\hline 14. Sexually transmitted infections can be transmitted from mother to unborn baby. & $317(73.0)$ & $61(14.1)$ & $56(12.9)$ \\
\hline 15. Using condom during sexual activity can always reduce the risk of getting STD. & $384(88.5)$ & $22(5.1)$ & $28(6.5)$ \\
\hline 16. Abstaining from sex can reduce the risk of getting STD. & $90(20.7)$ & $251(57.8)$ & $93(21.4)$ \\
\hline 17. Having only one partner can reduce the risk of getting STD. & $372(85.7)$ & $31(7.1)$ & $31(7.1)$ \\
\hline 18. Using withdrawal method can reduce the risk of getting STD. & $143(32.9)$ & $109(25.1)$ & $182(41.9)$ \\
\hline 19. Discharge from urethra or vagina is a symptom of STD. & $310(71.4)$ & $25(5.8)$ & $99(22.8)$ \\
\hline 20. Genital organs ulcer is a symptom of STD. & $305(70.3)$ & $21(4.8)$ & $108(24.9)$ \\
\hline 21. Vomiting is a symptom of STD. & $184(42.4)$ & $58(13.4)$ & $192(44.2)$ \\
\hline 22. Pain during sex is a symptom of STD. & $255(58.8)$ & $55(12.7)$ & $124(28.6)$ \\
\hline 23. Genital itching is a symptom of STD. & $336(77.4)$ & $15(3.5)$ & $83(19.1)$ \\
\hline 24. Headache is a symptom of STD. & $197(45.4)$ & $62(14.3)$ & $175(40.3)$ \\
\hline 25. Pain during urination is a symptom of STD. & $265(61.1)$ & $50(11.5)$ & $119(27.4)$ \\
\hline
\end{tabular}

\section{Discussion}

In this study, we showed that the level of sexual and reproductive health knowledge was low among postgraduate students. The lack of knowledge on sexual and reproductive health was reported in most of the developing countries [25]. Inadequate sexual health knowledge among youths may lead to risky behaviors, unsafe sexual practices, sexually transmitted diseases and unwanted pregnancies [26, 27]. This finding is consistent with a study by Wong et al. [28] regarding sexual and reproductive health among university students in Malaysia [26]. Conversely, Simbar et al. [29] found greater levels of sexual and reproductive health knowledge among university students in Iran. This may be due to steady educational programs in Iranian university students [29]. There is evidence showing that sex education result in preventing high risk sexual behavior and it ia not associated with increasing sexual activity [30].

The present study showed that the contraceptive methods knowledge was also low in most of the postgraduate students. Our results are consistent with the finding of the other study among Lebanese university students [31]. In contrast, knowledge of contraceptive issues was reported in high level among university students in Greece [32] and Iran [29]. Recently all Iranian college students are educated about family planning at university, it seems that this cause to increase level of contraceptive knowledge among university students. These efforts should be adapted to their gender and their field of study, with improved educational program for non-medical students [29]. It seems that an educational program on contraception is also necessary for university students [29]. It has been shown that sex education that includes contraception does not increase sexual activity, but rather persuades correct and consistent use of contraception for preventing unwanted pregnancy and sexually transmitted diseases [30, 33].

The results of this study showed that many sources of information about sexual and reproductive health are available for university students. Despite these efforts, however, the lack of accurate knowledge and misconceptions about sexually transmitted diseases were seen. As 
Table 3 Relationship between socio-demographic factors, current educational status and sexual and reproductive health knowledge $(n=434)$

\begin{tabular}{|c|c|c|c|c|c|}
\hline Variable & Group & N (\%) & Mean score & Test & $p$-value \\
\hline \multirow[t]{2}{*}{ Gender } & Male & $93(21.4)$ & 30.989 & $t=1.751$ & 0.082 \\
\hline & Female & 341 (78.6) & 29.343 & & \\
\hline \multirow[t]{2}{*}{ Age (year) } & $<26$ years & $265(61.1)$ & 29.034 & $t=-2.167$ & $0.031^{*}$ \\
\hline & $\geq 26$ years & 169 (38.9) & 30.733 & & \\
\hline \multirow[t]{2}{*}{ Ethnic } & Malay & 305 (70.3) & 29.459 & $t=-0.899$ & 0.37 \\
\hline & Non- Malay & $129(29.7)$ & 30.255 & & \\
\hline \multirow[t]{2}{*}{ Religion } & Muslim & $317(73)$ & 29.425 & $t=-1.118$ & 0.265 \\
\hline & Non- Muslim & $117(27)$ & 30.427 & & \\
\hline \multirow[t]{2}{*}{ Marital status } & Married & $94(21.7)$ & 31.904 & $t=3.26$ & $0.001^{*}$ \\
\hline & Single & $340(78.3)$ & 29.085 & & \\
\hline \multirow[t]{2}{*}{ Year of study } & First year & $349(80.4)$ & 29.352 & $t=-1.842$ & 0.068 \\
\hline & Others & 85 (19.6) & 31.105 & & \\
\hline \multirow[t]{3}{*}{ Faculty } & Non- science & $108(24.9)$ & 26.546 & & $0.000^{*}$ \\
\hline & Science & $263(60.6)$ & 29.4981 & $F=29.103$ & \\
\hline & Health science & $63(14.5)$ & 35.9206 & & \\
\hline
\end{tabular}

*Level of significance $(p<0.05)$

the results indicated, over half of the students believed that sexually transmitted diseases were spread by using public toilet, through kissing and shaking hands. It seems they do not have enough knowledge about transmission of sexual diseases. Furthermore, there are other factors that may affect the level of sexual knowledge, such as religious values and cultural sensitivities. Topics on sexual issues are still considered a taboo in this society and students are not exposed to such matters [28]. Similar misconceptions regarding prevention of sexually diseases were observed among university students in two previous studies in Malaysia [23, 28]. These findings may also suggest that there is insufficient education and coverage of such content by the mass media and educational institutions [23].

The current study showed that married and older students had higher mean knowledge score compare with

Table 4 Multiple linear regression analysis showing factors associated with sexual and reproductive health knowledge

\begin{tabular}{lllllll}
\hline Models & $\begin{array}{l}\text { Unstandardized } \\
\text { coefficients } \beta\end{array}$ & $\begin{array}{l}\text { Std. } \\
\text { error }\end{array}$ & $\mathrm{t}$ & Sig. & \multicolumn{2}{l}{$\begin{array}{l}95 \% \text { confidence } \\
\text { interval for } \beta\end{array}$} \\
\hline (Constant) & 46.354 & 4.671 & 9.924 & .000 & 37.173 & 55.535 \\
Marital status & -3.507 & 1.095 & -3.203 & $.001^{*}$ & -5.659 & -1.355 \\
Faculty & -4.655 & .620 & -7.50 & $.000^{*}$ & -5.875 & -3.436 \\
Gender & -.948 & .905 & -1.047 & .296 & -2.727 & .831 \\
Age & .040 & .105 & .381 & .704 & -.167 & .247 \\
Ethnic & -.733 & .662 & -1.10 & .268 & -2.033 & .567 \\
Religion & 329 & .502 & .655 & .513 & -.658 & 1.315 \\
Year of study & .417 & .567 & .736 & .462 & -.697 & 1.531 \\
\hline
\end{tabular}

*Level of significance $(p<0.05)$ younger students. As individuals grow older, their sexual curiosity and development lead them to seek for more information relating to sexual issues. These findings were consistent with those of other similar studies on Malaysian university students $[20,23]$. Furthermore, the results of the present study showed students in health science faculties had higher sexual and reproductive knowledge than other students. This fact may be somewhat due to the university courses that cover subjects on sexual and reproductive health. These results were supported by a study among Iranian university students [29]. Furthermore, an educational program on sexual and reproductive health is necessary for non-science students.

In the present research, the most frequently referred sources of sexual and reproductive health information were the internet and newspaper while the least frequent sources were parents and friends. These results are in line with those of two similar studies in Turkey and Malaysia among university students [34, 28]. In contrast a study of Chinese university students showed that the majority of the students gained sexual information by magazines and friends [35]. Anticipatory, parents are important source of information on sexual matters; but that was not recognized by most students as a source of information [36]. This finding is consistent with the findings of Anwar et al. (2010) on awareness of school students related to sexually transmitted infections in Pulau Pinang, Malaysia, in which it was found families were the most uncommon sources of information on sexual matters [36]. The previous study in Malaysia revealed that students were less likely to communicate with parents 
about sexual issues because of the fear that their parents think they had engaged in sexual activity [28].

The use of self-administered questionnaires may be considered a limitation of the present study. Sexual issues are sensitive topics regarded taboos by many youths who are reluctant to talk aboutthem. This can also be a limitation of this study. A socially-desirable response bias and an information bias were considered in this study.

\section{Conclusions}

In conclusion, the finding of the current study showed that the level of sexual and reproductive health knowledge is not satisfactory and there are still some misconceptions about sexual issues. Inadequate knowledge may place students at risk of sexually transmitted infections including HIV/AIDS and unwanted pregnancy. Sexual and reproductive health knowledge was associated with marital status and faculty among students. Thus, educational programs in the form of short courses or peer education can improve the sexual and reproductive health knowledge among university students. In some studies, peer education has brought positive changes in all aspect of knowledge, attitude and practice [37].

\section{Abbreviations \\ AIDS: Acquired immune deficiency syndrome; CDC: Centers for disease control and prevention; MLR: Multiple linear regression; HIV: Human immunodeficiency virus; SRH: Sexual and reproductive health; STD: Sexually transmitted disease; UPM: Universiti Putra Malaysia; UNAIDS: United Nation Joint Program on HIV/AIDS; UNGASS: United Nations General Assembly Special Session on HIV/AIDS; WHO: The World Health Organization.}

\section{Competing interests}

The authors declare that they have no competing interests.

\section{Authors' contributions}

SS wrote the proposal, design of the questionnaire, participated in data collection, analyzed the data and drafted the manuscript. HAR supervised all stages of design, implementation, analysis, interpretation and revised the manuscript. RL supervised all stages of design, implementation, analysis, interpretation and revised the manuscript. NAMZ supervised all stages of design, implementation and revised the manuscript. NM participated in the preparation of the manuscript, data analysis and revised the manuscript. All authors read and approved the final manuscript.

\section{Acknowledgments}

We wish to extend our thanks to Dean of Faculty of Medicine and Health Sciences. Special thanks to Universiti Putra Malaysia for permission to conduct this study. Our thanks are due to the postgraduate university students for their participation.

\section{Author details}

'Department of Community Health, Faculty of Medicine and Health Sciences, Universiti Putra Malaysia, 43400 UPM, Serdang, Malaysia. ${ }^{2}$ Department of Nursing, College of Science, Hamedan branch, Islamic Azad University Hamedan, Hamedan, Iran.

Received: 27 June 2014 Accepted: 12 August 2015

Published online: 29 August 2015

\section{References}

1. United Nations: World Summit Outcome. Resolution adopted by the General Assembly, New York, U.N; 2005. Retrieved October 24, 2005, from [http://www.un.org/womenwatch/ods/A-RES-60-1-E.pdf].
2. World Health Organisation (WHO): Draft working definition on Sexuality World Health Organisation, Geneva; WHO, 2002. Retrieved 24 Aug 2015 from [http://www.who.int/reproductivehealth/topics/sexual_health/ sh_definitions/en/index.html].

3. World Health Organization: Sexually transmitted infections; 2011. Retrieved 24 Aug 2015, from. [http://www.who.int/topics/ sexually_transmitted_infections/en/].

4. Centers for Disease Control and Prevention. Sexually Transmitted Disease Surveillance. Atlanta: U.S. Department of Health and Human Services; 2011. Retrieved April 25, 2011, from [http://www.cdc.gov/std/ stats11/surv2011.pdf]

5. UNAIDS/ WHO: Report on the Global AIDS Epidemic. Preventing New HIV Infection. Geneva: UNAIDS. UNGASS; 2008. [http://data.unaids.org/pub/ GlobalReport/2008/jc1511_gr08_executivesummary_en.pdf].

6. Bensyl D, Iuliano A, Carter M, Santelli J, Gilbert B. Contraceptive Use, United States and Territories, Behviorral Risk Factor Surveillance System, Atlanta. Morbidity and Mortality Weekly Report Survailance Summary. 2005;54:1-72.

7. Mosher WD, Martinez GM, Chandra A, Abma JC, Willson SJ. Use of contraception and use of family planning services in the United States. Nat Center for Health Stat. 2004;350:1-36.

8. Centers for Disease Control and Prevention (CDC): Unintende Pregnancy; 2011. Available at: [http://www.cdc.gov/reproductivehealth/unintendedpregnancy/]

9. Low WY. Malaysian Youth Sexuality, Issues and Chalenges. J Univ Malaya Med Centre. 2009;12:3-14.

10. Lee LK, Chen PC, Lee KK, Kaur J. Premarital sexual intercourse among adolescent in Malaysia: a cross-sectional Malaysian school survey. Singapore Med J. 2006;47:476-81.

11. Ministry of Health Malaysia: Annual Report on HIV/AIDS epidemic; 2008. December 2008. http://www.moh.gov.my/images/gallery/publications/mh/ Malaysia\%20Health\%202008-2.pdf].

12. Manlove J, Terry E, Gitelson L, Papillo AR, Russell S. Explaining demographic trends in teenage fertility, 1980-1995. Fam Plann Perspect. 2000;32:166-75.

13. Abdullah R. Abortion in Malaysia: legal yet still inaccessible. Arrows Change. 2009;15:8-9.

14. Noordin N, Zakaria Z, Sawal MM. The Voice of Youngsters on Baby Dumping Issues in Malaysia. Int I Trade, Economics Financ. 2012;3:66-72.

15. New Straits Times: "Foetus found buried by roadside" 2010. Retrieved Jul 18, 2010 from [http://www.highbeam.com/doc/1P1-182145782.html].

16. Rahman A, Rahman R, Ibrahim MI, Salleh H, Ismail SB, Ali SH, et al. Knowledge of sexual and reproductive health among adolescents attending school in Kelantan, Malaysia. Southeast Asian J Trop Med Public Health. 2011;42:717-25.

17. Mahtab, M: Knowledge, Attitude and Practice Related to HIV/AIDS Prevention Among Secondary School Students in Klang, Malaysia. Master thesis, Universiti Putra Malaysia. Community Health Department; 2010.

18. Normala I, Zubaidah JO, Shaliza HN, Hamidin A, Noorjan KON, Fadhilah ISI, et al. Sound HIV Knowledge and Common Misconceptions About HIV Among University Students. Malaysian J Med Health Sci. 2013;9:29-34.

19. Rozina R, Lekhraj R, Lye MS, Hejar AH. Knowledge, Attitude and Practice Related to HIV/AIDS among Students in a Local University. Malaysian J Med Health Sci. 2007;5:27-41.

20. Low WY. Impact of sexual health course on Malaysian university students. Med J Malaysia. 2004;59:443-9.

21. Tee Y, Huang M. Knowledge of HIV/AIDS and attitudes towards people living with HIV among the general staff of a public university in Malaysia. J Soc Aspects HIV/AIDS. 2009;6:144-17.

22. Centers for Disease Control and Prevention (CDC): Reproductive Health Survey Albania Final Report. Department of Health and Human Services; 2002 [http://stacks.cdc.gov/view/cdc/8243]

23. Jahanfar S, Lye MS, Rampal LA. Randomised controlled trial of peer-adult-led intervention on improvement of knowledge, attitudes and behaviour of university students regarding HIV/AIDS in Malaysia. Singapore Med J. 2009;50:173-80

24. 24. Lemeshow, S., Hosmer, D. W., Klar, J., \& Lwanga, K. Adequacy of Sample Size in Health Studies. Chichester 1990, published on behalf of the World Health Organization.

25. Regmi PR, Simkhada P, Van Teijlingen ER. Boys remain prestigious, girls become prostitutes: socio-cultural context of relationships and sex among young people in Nepal. Global J Health Sci. 2010;2:60-72.

26. Williamson LM, Parkes A, Wight D, Petticrew M, Hart GJ. Limits to modern contraceptive use among young women in developing countries: a systematic review of qualitative research. Reprod Health J. 2009;6:1-12. 
27. Rani M, Lule E. Exploring the socioeconomic dimension of adolescent reproductive health: A multicountry analysis. Int Fam Plan Perspect. 2004;30:110-7.

28. Wong LP. An exploration of knowledge, attitudes and behaviours of young multiethnic Muslim-majority society in Malaysia in relation to reproductive and premarital sexual practices. BMC Public Health. 2012;12:865.

29. Simbar M, Tehrani FR, Hashemi Z. Reproductive health knowledge, attitudes and practices of Iranian. East Mediterr Health J. 2005;11:888-97.

30. Kirby DB, Laris BA, Rolleri LA. Sex and HIV education programs: their impact on sexual behaviors of young people throughout the world. J Adolesc Health. 2007:40:206-17.

31. Barbour B, Salameh P. Knowledge and practice of university students in Lebanon regarding contraception. East Mediterr Health J. 2009;15:387-99.

32. Tountas Y. Information sources and level of knowledge of contraception issues among Greek women and men in the reproductive age. Eur ] Contracept Reprod Health Care. 2004;9:1-10.

33. Klein JD. Adolescent pregnancy, current trends and issues. Am Acad Pediatr. 2005;116:281-6.

34. Rathfisch G, Aydin M, Pehlivan MD, Bozurt BS, Kaplica I. Evaluation of reproductive health and sexual behaviors of university students: case study from Istanbul. Contemp Nurse. 2012;43:47-55.

35. Zhou H, Wang XY, Fang YE, Hai-hua GUH, lily ZX. Contraceptive knowledge, attitudes and behavior about sexuality among college students in Beijing, China. Chinese Med J. 2012;125:1153-7.

36. Anwar M, Sulaiman SAS, Ahmadi K, Khan TM. Awareness of school students on sexually transmitted infections (STIs) and their sexual behavior: a cross-sectional study conducted in Pulau Pinang, Malaysia. BMC Public Health. 2010;10:47.

37. Merakou K, Kourea-Kremastinou J. Peer education in HIV prevention: an evaluation in schools. Eur J Public Health. 2006;16:128-32.

\section{Submit your next manuscript to BioMed Central and take full advantage of:}

- Convenient online submission

- Thorough peer review

- No space constraints or color figure charges

- Immediate publication on acceptance

- Inclusion in PubMed, CAS, Scopus and Google Scholar

- Research which is freely available for redistribution 